Ganna Likhonosova,

Ph.D., Associate Professor, Finance Department, National Aerospace University «Kharkiv Aviation Institute»,

Kharkiv, Ukraine

Galyna Lutsenko,

Teacher-methodologist of the highest category, Kremenchuk Flight College, National Aerospace University «Kharkiv Aviation Institute», Kremenchuk, Ukraine

\title{
ASSESSMENT WELFARE OF THE POPULATION IN THE SYNERGETIC SYSTEM OF SOCIO-ECONOMIC EXCLUSION
}

The research confirmed that in order to carry out a comprehensive multi-level diagnosis of the well-being of the population, it is necessary to systematize the most important social, economic and other types of indicators. The authors developed a multilevel approach to implement the tools for diagnosing the population welfare: at the international, national, regional, territory and local levels. It is proved that socio-economic exclusion is the result of the law of the synergetic development of the system, that is, a law that expresses internally necessary, stable connections between elements of the system that determine the level of system synergy. The system of estimation indicators of population welfare is generalized taking into account its multilevel dimension. The complex of factors is determined, under the influence of which the level of population welfare changes. The authors develop methodological and applied aspects of the choice of a multilevel approach to estimate the population welfare through the neutralization of the negative effects of exclusion and the promotion of population improvement in different regions. The conducted studies allowed to confirm the results obtained regarding the choice of instruments to overcome existing problems and disproportions in society. The introduction of a multi-level approach to evaluate the population welfare could directly affect to the level of life quality of the population and progressive socio-economic development. Avoidance of regional disproportions in development and rejection processes taking place in the state is possible taking into account from the different point of views on the specificity of socio-economic development of each region. Monitoring of the coherence of the public communities actions and governmental organizations could ensure the achievement of a high quality living standard of the population, which enable each individual member of the community to implement their own rational-selfish development goals, which trigger the loop of feedback with a multiplicative positive effect.

Keywords: welfare, multilevel approach, assessment, socio-economic exclusion, synergy.

Formulation of the problem. In today's conditions of the population development of any country, it seeks to change the level of its life and to improve some of its components. The social development of the country is characterized by the presence of complex problems and a significant decrease in the level and quality of life of the population, which is conditioned, first of all, by the crisis slump in production and the processes of a deep bundle of society in terms of income. Today, when one of the most important target plants is the achievement of world standards, Ukraine seeks to integrate into the world and European spaces, therefore, in these conditions, the issue of the need to improve approaches to the diagnosis of 
the socio-economic situation of the population becomes of particular urgency and significance. The updating of this problem is intensified by the spread of processes of socio-economic exclusion, as a phenomenal phenomenon of seizing the personality from the surrounding society. Such processes acquire not only locally-regional scale but tend to spread to all spheres of activity and life support of a person. The socio-economic development of the country, as the main objective of any state policy, is defined as a longterm process of transformation in the economy, covering quantitative and qualitative changes, which results in the growth of the well-being of a single average person and society as a whole.

The formation of the welfare of the population of Ukraine occurs under the influence of many factors that affect the special conditions for meeting the needs of citizens. The development and establishment of market relations over the last decade was accompanied by a number of negative trends such as a significant reduction in income, growing wealth and social class differentiation of society, the widespread of poverty, the decline of industrial production, unemployment, rising prices and the complexity of adapting people to new economic conditions, hampered the economic and social growth of the state. All these factors trigger the emergence of socio-economic exclusion, which makes impossible the full socioeconomic development of the country. The exclusion is manifested, in particular, because of the inability of certain segments of the population to obtain high-quality medical and educational services precisely because of their too high value. Usually, such economic barriers block social and public initiatives of the individual, deprive the economic opportunity to be a full member of society. Consequently, the issue of developing a system of indicators for diagnosing the level and quality of life of the population, making changes to the modern welfare concept, reflecting its structure and characteristics, remains open and requires further research.

Analysis of recent researches and publications. The problems of estimating the welfare of the population with the help of a system of indicators are devoted to the scientific development of many foreign (R. Adams, P. Samuelson, T. Parsons, A. Bigtens, R. Barro, C. Bywalec [1, p. 191-202] and domestic authors [2], A.Srinchova, L. Lisogor, V. Pryimak [3, p. 149-158], O. Makarova [4, p. 10-15] and others), who proposed ways of measuring welfare, poverty, investigated the relationship between the dynamics of indicators that characterize them and economic growth. However, such issues as identification and systematization of indicators of measuring not only economic but also social welfare, in general, remain open.

Speaking about the socio-economic exclusion of the population, a priori predict the aspirations of the population (as part of the system-society) to preserve its integrity. The main tendency in the behaviour of such an exclusion system is, as far as possible, to be from a state of chaos and static equilibrium. On the other hand, synergetic products argue that there is no development in the absence of instability. That is, development is only due to instability, bifurcation, and chance. The methodology of synergetic in this study is proposed to be viewed from the point of view of the laws of the development of the system $[5, p .101$. 106] and the Darwinian triad [6, p.22-28].

The emphasis on unsolved aspects of the general problem. Consequently, internal social and economic turmoil and external crises contribute to the identification and selection of the best qualities, conditions, and criteria for the quality of life of the population. Attraction, the leaders or leaders of the refractory system, strategically planning the possible boundaries of this area of instability, the area of its permissible randomness, deliberately introduces the system to such a socio-economic state, to intensify the processes of self-determination and hidden development reserves. Thus, at risk, the socio-economic system develops through the constant struggle with entropy, namely, the factors of exclusion.

The aim of this article is to diagnose the welfare of the population based on the application of a multilevel approach and to identify ways to improve the well-being of the Ukrainian population by eliminating the factors of exclusion.

Basic material. At present, the development of a system of indicators for the welfare of the population 
is of paramount importance for an integrated multi-level analysis of the socio-economic development of modern society. To this end, two fundamentally important approaches are used: a system that involves taking into account the influence of all factors of economic development on the welfare of the population and allows constructing a system of formation of integral priorities and mechanisms for their implementation; integral, which provides for two kinds of assessments: objective, that is, based on official statistics, without involving aggregate information based on various types of surveys and subjective assessments based on sociological surveys.

In order to conduct a comprehensive multi-level diagnosis of the well-being of the population, it is necessary to systematize the most important social, economic and other types of indicators that will provide a quantitative and qualitative assessment of modern socio-economic processes, taking into account the influence and significance of the factors on them. Diagnostics of the welfare of the population should be conducted taking into account the multilevel approach, that is, at the global, national, regional, sectoral, local and local levels (Figure 1).

At the same time long-term guidelines in the social sphere can be considered creation of conditions for a decent living standard of the population, the development of labour potential, the prevention of excessive differentiation of the population by income, the implementation of pension reform, the provision of targeted support to vulnerable segments of the population, the comprehensive development of education, culture, improvement of protection health of the population. At the moment, there are a number of difficult problems: the general level of incomes remains low according to the standards of the countries not only with developed but also with the transition economy; the estimation of the welfare of the population by the average indicators conceals the growth of the separation of wealthy layers from the rest of the population, there are significant regional differences in income levels, etc.

One of the important tasks of modern socio-economic macro statistics both in Ukraine and abroad is the improvement of the system of indicators of the welfare of the population, depending on the spatial distribution of the population of the globe, taking into account the factors of socio-economic exclusion.

Proceeding from the fact that the carriers (often unconscious) of the potential of the socio-economic system, its capabilities and properties are the concrete people who possess all biological peculiarities, to describe the processes of socio-economic exclusion as a holistic functioning system, we propose to apply the Darwinian triad of principles of organization - heredity, variability, selection.

The continuity of the socioeconomic system is the dependence of its future from the present and the past, using the term "memory of the system". That is, it can be assumed that under the present state of the socioeconomic system it is possible to restore its past achievements and defeats and, moreover, to predict its behaviour in the future, building a strategy for the development of this system. With confidence, it can be argued that this is quite possible. These issues are successfully solved by strategic and tactical prediction of the state of the system based on existing indicators of its functioning and their subsequent monitoring. Therefore, this principle can act as one of the conditions for the exclusion of the socioeconomic system in order to reach a new stage in its development;

Variability as a process can be observed in any socio-economic system. There are many reasons for generating changes in society. As the complexity of its organizational form, the increase of social and economic load, the probability of stochastic, unforeseen factors increases. Because of the internal social activity of mobility, the imbalance of the received income is a certain accumulation of disturbances, as a result, within a certain society (enterprise collective, regional personification, etc.) stability is lost and there is a transition of a part of society from one level of evolutionary development to another. Optional, this will be the best level, but necessarily - a new one. The result is the emergence of a part of the rejected social, justified by socio-economic reasons. 


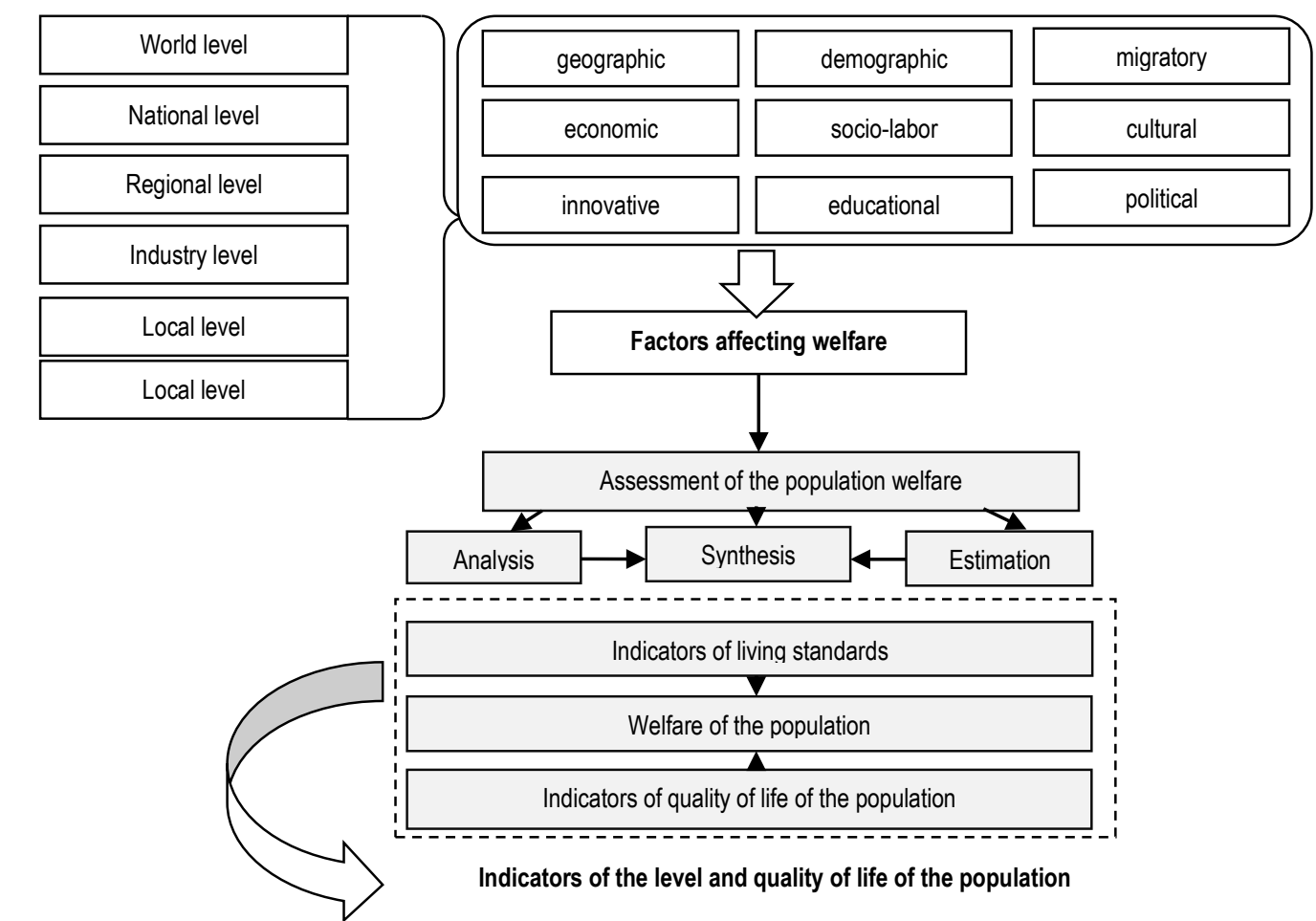

World level: Human Development Index (HDI); index of intellectual potential of a society (IIPS); per capita human capital (PCHC); viability rate of the population (VRP); minimum per capita income; GDP per capita for the poor; gross domestic product per capita; consumer price index; the dynamics of morbidity, fertility, mortality; unemployment rate; maternal mortality rate; share of environmental costs in GDP and so on.

National level: Growth rate of GNP; the growth rate of labor productivity; the share of foreign investment in the total volume of investments in the country; national income per capita; R \& D as a percentage of GNP; share in the country's exports of raw materials, labor-intensive and capital-intensive industries; share in world export and import of goods; the level of incomes in the families of workers and employees real incomes and their purchasing power, minimum wages, etc.

Regional level: GRP per capita; average monthly nominal wage; index of consumer prices for foodstuffs; purchasing power of cash receipts; Gini coefficient; consumer spending per capita; Percentage of purchases of goods and payment of services in the structure of use of cash income of the population; capital investment per capita; the percentage of growth of financial assets in the structure of use of cash income of the population; expected life expectancy at birth; the ratio of the number of marriages and divorces; unemployment rate, etc.

Sectoral level: Level of labor productivity; specific wages capital intensity and high technology; technical level of products; the degree of export orientation and import dependence of the industry; the degree of use of products in various industries; the level of alignment and progressiveness of the research and development production and technological base, etc.

Oblast level: The level of competitiveness of products in terms of price and non-price characteristics; the level of quality of products and services; level of qualification of the labor force; technological level of production; selling price and operating costs; production and sales costs; the level of knowledge-intensive products; supply and demand; solvency, etc.

Local level: Level of local incomes and business activity and quality of working life; level of personnel qualification; the number of ablebodied people in the household; level of quality of housing, improvement of the territory of the housing stock; pensions, help for the poor and the disabled, the level of social insurance; crime rate, etc.

\section{Figure 1 - Information base for the assessment of the population welfare based on the multilevel approach}


Selection in society is carried out on the basis of certain existing criteria or stereotypes. From the opposite point of view, there are laws, dependencies, and rules, violating which society moves to selfdestruct. The simplest example of economic exclusion is the unsuccessful choice of business activity. The selection has a powerful force it outlines the many viable forms of socio-economic organization. Remember that any society is part of the socio-economic system a higher level (sectorial, national or global), which imposes restrictions on their specific operation of the system, its structure and processes of exclusion, in particular. This great powerful system rejects those options for the development of individual elements that hinder its own development path. Therefore, the development of the socioeconomic system depends on its compliance with the functions that it performs as an element of the systems of mego-, macro-, meso- and micro-levels.

Analysis and evaluation of welfare in mego (global) level through a comprehensive assessment of the most important integral indicators of the economy on the external and internal parameters: the human development index, the index of the intellectual potential of society, human capital per capita coefficient viability of the population, the lowest per capita income, GDP Per capita, the share of environmental costs in GDP, the formation and change of which occurs under the influence of many factors, such as: scientific and technical progress in all sectors, growth of the world population, conditions for growth of incomes, migration, inflation, investments in the country, foreign economic policy and relations, functions of the world monetary system, etc. An assessment of the level of welfare achieved by countries provides an opportunity to rank them in accordance with the achieved level of values of the relevant criteria and indicators. The Human Development Index is an integral indicator that has been created to study the development of the human potential of countries [7, p. 66-74]. This Index is a standard indicator of comparing the standard of living of citizens from different countries and regions published annually by the United Nations Development Program.

The authors analysed 187 countries that are members of the UN, as well as Hong Kong, the Special Administrative District of China and the Occupied Palestinian Territories. The basis of the index consists of three indicators: life expectancy in the country, the level of education of the adult population, and the ratio of those receiving education at primary, secondary and higher education, and gross domestic product.

The United Nations Multilevel Human Development Indicator System, which has been created, covers almost all essential aspects of life and provides an opportunity to monitor changes in human development. Within the framework of the study, the emphasis was placed on 30 states, which were divided into groups from "a country with a very high level of human development" to "a country with a low level of human development". For countries with a very high level of human development, the United Nations includes: Norway, Germany, USA, Canada, Japan, France, Italy, Poland and other countries; Countries with a high level of human development - Belarus, Russia, Kazakhstan, Bulgaria, Turkey, Brazil, Ukraine, China and etc.; Countries of the middle level of human development - Moldova, Egypt, Uzbekistan, Iraq, India, Congo and others; Pakistan, Madagascar, Mauritania, Afghanistan, Guinea, Chad, Central African Republic, Niger are among the countries with low human development (Table 1).

The dynamics of national achievements in the field of development of HDI in 2015 reflects the progress in this field: most countries of the world have continued to converge towards a higher level of human development. At the same time, the pace of progress with regard to HDI was higher in countries with high and average levels of human development. In 2015, Ukraine ranked 81st in the country's ranking of the Human Development Index, yielding to Brazil and ahead of China, rising to 2 positions - from 83 in 2014. This indicator belongs to the category of high level of development. The HDI of Ukraine in 2015 was 0.747 points, which puts it in the second group of general rating. For the period from 1990 to 2015, the value of Ukraine's HDI increased from 0.705 to 0.747 - that is, by $6 \%$ (on average - by $0.024 \%$ per year). 
Table 1 - The index of human development in the world and the dynamics of its key indicators in 2014-2015 [8]

\begin{tabular}{|c|c|c|c|c|c|c|c|c|c|c|c|c|}
\hline \multirow[t]{2}{*}{$\begin{array}{l}\text { Country } \\
\text { names }\end{array}$} & 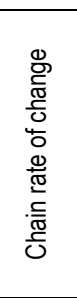 & $\begin{array}{c}\mathrm{HDI}, \\
\text { meaning }\end{array}$ & 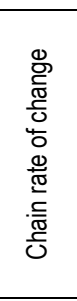 & $\begin{array}{c}\text { Expected } \\
\text { life } \\
\text { expectancy } \\
\text { at birth, } \\
\text { years }\end{array}$ & 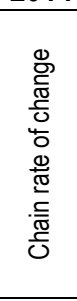 & $\begin{array}{c}\text { Expected } \\
\text { years of } \\
\text { study, } \\
\text { years }\end{array}$ & 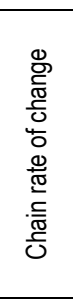 & $\begin{array}{c}\text { The } \\
\text { average } \\
\text { duration } \\
\text { of } \\
\text { studies, } \\
\text { years }\end{array}$ & 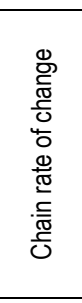 & $\begin{array}{c}\text { GDP } \\
\text { per } \\
\text { capita, } \\
\text { PPS \$ }\end{array}$ & $\begin{array}{c}\text { GDP } \\
\text { per } \\
\text { capita } \\
\text { minus } \\
\text { the } \\
\text { rank } \\
\text { of HDI } \\
\text { PKP \$ }\end{array}$ & \begin{tabular}{|} 
Change \\
the rank \\
value \\
according \\
to the \\
value for \\
the \\
previous \\
period \\
\end{tabular} \\
\hline & চ্ঠি & $\stackrel{\circ}{\check{N}}$ & চ্ণ & $\stackrel{n}{2}$ & চ্ঠি & $\stackrel{n}{\sim}$ & চ্ঠি & $\stackrel{n}{\circ}$ & চ্ঠি ঠ্ঠ & $\stackrel{n}{\check{N}}$ & $\stackrel{n}{\circ}$ & \\
\hline \multicolumn{13}{|c|}{ A group of countries with a very high level of human development: } \\
\hline Norway & 1,46 & 0,944 & 3,23 & 81,6 & $-2,11$ & 17,5 & $-3,33$ & 12,6 & 8,17 & 64,992 & 5 & $\begin{array}{l}\text { Change } \\
\text { has not } \\
\text { occurred }\end{array}$ \\
\hline Germany & 0,89 & 0,916 & 4,55 & 80,9 & 1,76 & 16,5 & 1,89 & 13,1 & 4,90 & 43,919 & 11 & $\begin{array}{l}\text { Change } \\
\text { has not } \\
\text { occurred }\end{array}$ \\
\hline USA & $-2,37$ & 0,915 & 3,33 & 79,1 & 1,48 & 16,5 & 0,97 & 12,9 & 7,33 & 52,947 & 3 & $\begin{array}{ll}\nabla & 3 \\
\end{array}$ \\
\hline Canada & $-5,76$ & 0,913 & $-2,23$ & 82,0 & 3,33 & 15,9 & 0,45 & 13,0 & 10,82 & 42,155 & 11 & $\nabla$ \\
\hline Japan & $-2,22$ & 0,891 & 5,43 & 83,5 & 1,37 & 15,3 & 0,54 & 11,5 & $-3,65$ & 36,927 & 7 & $\nabla$ \\
\hline France & $-1,46$ & 0,888 & 2,35 & 82,2 & 2,47 & 16,0 & $-1,28$ & 11,1 & $-2,82$ & 38,056 & 4 & $\nabla$ \\
\hline Italy & $-3,37$ & 0,873 & 4,44 & 83,1 & 2,47 & 16,0 & 0,13 & 10,1 & $-2,22$ & 33,030 & 4 & $\nabla$ \\
\hline Poland & $-4,12$ & 0,843 & $-1,22$ & 77,4 & 2,02 & 15,5 & 1,16 & 11,8 & $-3,14$ & 23,177 & 10 & $\nabla$ \\
\hline \multicolumn{13}{|c|}{ Group of countries with a high level of human development: } \\
\hline Belorussia & 1,03 & 0,798 & 2,22 & 71,3 & 1,34 & 15,7 & 3,31 & 12,0 & $-2,21$ & 16,676 & 14 & $\triangle$ \\
\hline Russia & 3,13 & 0,798 & 1,15 & 70,1 & 1,23 & 14,7 & 3,33 & 12,0 & 0,25 & 22,352 & -1 & $\triangle$ \\
\hline Kazakhstan & 4,21 & 0,788 & 0,35 & 69,4 & 3,32 & 15,0 & $-5,21$ & 11,4 & 0,04 & 20,867 & -1 & $\triangle$ \\
\hline Bulgaria & $-0,22$ & 0,782 & 2,23 & 74,2 & 2,13 & 14,4 & $-5,13$ & 10,6 & $-1,14$ & 15,596 & 13 & $\nabla$ \\
\hline Turkey & $-2,43$ & 0,761 & $-4,14$ & 75,3 & 1,23 & 14,5 & 2,37 & 7,6 & 3,13 & 18,677 & -12 & $\nabla$ \\
\hline Brazil & 0,98 & 0,755 & 3,13 & 74,5 & 1,23 & 15,2 & 2,13 & 7,7 & 2,26 & 15,175 & -1 & $\triangle$ \\
\hline Ukraine & 0,78 & 0,747 & 2,89 & 71,0 & $-7,36$ & 15,1 & $-8,87$ & 11,3 & $-10,44$ & 8,178 & 25 & $\triangle$ \\
\hline China & $-0,21$ & 0,727 & 3,45 & 75,8 & $-4,44$ & 13,1 & 1,45 & 7,5 & 5,65 & 12,547 & -7 & $\triangle$ \\
\hline \multicolumn{13}{|c|}{ A group of middle-income countries: } \\
\hline Moldova & 0,45 & 0,693 & 2,33 & 71,6 & 1,45 & 11,9 & 6,55 & 11,2 & 2,23 & 5,223 & 23 & $\triangle$ \\
\hline Egypt & 1,21 & 0,690 & 2,31 & 71,1 & 3,13 & 13,5 & $-1,15$ & 6,6 & 2,24 & 10,512 & -12 & $\triangle$ \\
\hline Uzbekistan & 0,78 & 0,675 & 1,45 & 68,4 & 2,11 & 11,5 & 0,89 & 10,9 & 1,47 & 5,567 & 10 & $\triangle$ \\
\hline Iraq & $-2,21$ & 0,654 & $-2,03$ & 69,4 & 1,12 & 10,1 & $-3,12$ & 6,4 & 2,27 & 14,003 & -44 & $\nabla$ \\
\hline India & 1,12 & 0,609 & $-3,12$ & 68,0 & $-2,14$ & 11,7 & 0,55 & 5,4 & 2,22 & 5,497 & -4 & $\triangle$ \\
\hline $\begin{array}{l}\text { Republic of } \\
\text { the Congo }\end{array}$ & 0,87 & 0,591 & $-4,14$ & 62,3 & 1,15 & 11,1 & $-2,21$ & 6,1 & 3,35 & 6,012 & -14 & $\triangle$ \\
\hline Bangladesh & 0,02 & 0,570 & $-3,12$ & 71,6 & 1,17 & 10,0 & $-1,17$ & 5,1 & 1,15 & $\begin{array}{c}3,191 \\
5\end{array}$ & 5 & $\triangle$ \\
\hline \multicolumn{13}{|c|}{ A group of low-income countries: } \\
\hline Pakistan & $-5,46$ & 0,538 & $-6,31$ & 66,2 & 8,12 & 7,8 & $-4,12$ & 4,7 & 2,71 & 4,866 & -14 & $\nabla$ \\
\hline Madagascar & 0,09 & 0,510 & 2,12 & 65,1 & 1,43 & 10,3 & $-1,21$ & 6,0 & 1,54 & 1,328 & 24 & $\triangle$ \\
\hline Afghanistan & $-3,21$ & 0,465 & 0,79 & 60,4 & 1,65 & 9,3 & 0,56 & 3,2 & 1,92 & 1,885 & -7 & $\nabla$ \\
\hline Guinea & $-1,43$ & 0,411 & 1,13 & 58,8 & 0,54 & 8,7 & 0,32 & 2,4 & 1,13 & 1,096 & 0 & $\nabla$ \\
\hline Chad & $-2,12$ & 0,392 & $-2,07$ & 51,6 & 0,12 & 7,4 & 0,79 & 1,9 & 3,21 & 2,085 & -22 & $\nabla$ \\
\hline $\begin{array}{l}\text { The central } \\
\text { African } \\
\text { republic }\end{array}$ & $-2,12$ & 0,350 & $-1,21$ & 50,7 & 0,24 & 7,2 & $-0,31$ & 4,2 & $-1,15$ & 0,581 & 1 & $\nabla$ \\
\hline Niger & $-1,32$ & 0,348 & $-1,54$ & 61,4 & 0,32 & 5,4 & $-1,48$ & 1,5 & 0,42 & 0,908 & -5 & $\nabla$ \\
\hline
\end{tabular}


In the world, for the studied periods, HDI has grown by an average of 2,345 - that is three times more than in Ukraine. Progress over the years was achieved at the expense of the poorest countries, but the countries of the first group - with the highest HDI - Increased it by 1,574. That is almost twice as much as Ukraine. In the period from 2014 to 2015, the value of the human development index in Ukraine increased by an average of 0.78 , which was achieved on the basis of principles of continuity and volatility, as conditions for the prevention of social exclusion, etc. But, on the other hand, the slight change in the HDI in Ukraine for the analyzed period quickly influenced the beginning of the socio-economic collapse, which greatly worsened the position of Ukraine in the global environment.

For the diagnosis of welfare of the population at the macro level it is proposed to use the following indicators [9, p. 53-65]: the growth rate of GNP and labour productivity; the share of foreign investment in the total volume of investments in the country; national income per capita; R \& $D$ as a percentage of GNP; share in the country's exports of raw materials, labour-Intensive and capital-intensive industries; share in world export and import of goods; the level of incomes in the families of workers and employees, the real incomes of the population and their purchasing power, etc. However, the dynamics and overall value of these indicators can be influenced by new, not always positive factors [10, p. 218-226].

Undoubtedly, social and economic exclusion is the result of the law of the synergetic development of the system, that is, a law that expresses the internally necessary, constant and essential links between the elements of the system that determine the level of system synergy, the correlation between the adequacy of the synergistic base of the system and the need to increase the system's activity, for obtaining a synergistic effect, which ensures the further development of this base [11, p. 218-226]. This law justifies the fact that in any social-economic system is ignored and considered potential - the latter is considered as a base for development, and only when the complete destruction of this base is the elimination of the system itself. Depending on the nature of the activity of using the development factors of the system, the basic level of system synergy over a specific period of time may be increased or decreased, which corresponds to the size of the resulting, respectively, positive or negative synergistic effect. Consequently, at a predetermined interval of time, there are two opposite processes that change the synergetic value of the object: the outflow or accumulation of synergy.

If the total outflow of synergy exceeds the amount of its accumulation there is a decrease in the value of the base synergy, and, accordingly, there is a regressive development, the base of the system decreases. A certain amount of further synergistic development of the system will be of a relative nature, will be aimed at restoration of the basic level. The intense accumulation of synergy in the system is positive, with the total build-up of the basic synergetic of the system.

Proceeding from this, synergy is the ability of a particular system at a particular time point due to the interaction of specific elements of the system or the influence of another system on the subject to cause the effects of "expansion" or "compression". Turning to the effects of "expansion" and "compression", it is appropriate to emphasize that they can have a positive - progressive or negative - regressive character.

In order to elaborate on the synergistic effect of socio-economic exclusion, we will determine the scale of this phenomenal phenomenon through synergistic algorithms. For the a system, we select the Ukrainian society, according to the system $\beta$ we will consider the scale of people who are under the influence of factors of socio-economic exclusion. The mentioned factors of socio-economic exclusion have already been detailed in copyright research [6, p. 22-28].

$$
S_{t} \alpha=E_{t} \alpha+S_{\beta} \pm \Delta S_{\alpha \beta}
$$

$S_{t} \alpha$ - synergistic effect at a specific moment of time (t) in the system $\alpha$;

$E_{t} \alpha$ - the initial effect in the system $\alpha$;

$S_{\beta}$ - the synergistic effect of expansion in the system $\beta$, that is, the effect of the system a on the 
system $\beta$;

$\Delta S_{\alpha \beta}$ - the effect of the inverse synergistic effect of the $\beta$ system on the system $\alpha$.

Regarding the methodological features of synergetic social and economic exclusion, it is worth noting the basic laws:

1. As a result of the functioning of the $\beta$ system within the system $\alpha$, the positive synergistic effect of the system $\beta$ has the size $£$ and exceeds the time created and the initial effect of the system created $\alpha$ :

$$
S_{\beta} \geq \mathrm{E}_{\alpha}
$$

2. The synergistic effect of socioeconomic exclusion cannot be fully structured beforehand, its value cannot be precisely determined because it has a probabilistic nature of the offensive:

$$
S_{\beta}=p\left(S_{\alpha}\right)
$$

where $p\left(S_{\alpha}\right)$ - is the probability of an event occurring $£$.

3. The synergistic effects of social and economic exclusion are inherent in the general features of a complex system, namely: the existence of a system of direct and inverse relationships between all the constituent elements of socio-economic exclusion, on the basis of which synergetic effects take place; trends in the effectiveness of socio-economic development of socio-economic formations; the scale of the synergistic effects of socio-economic exclusion depends on the peculiarities of social inclusion or failure to take into account in its functioning the general methodology of social development as a complex open system.

4. The existence in the socioeconomic system of various synergetic system levels (social: micro, meso-, macro-, mega), that is, the "synergistic matryoshka" effect, characterized by different directions of direct and inverse relationships and the strength of synergistic influence. Each level is interdependent with another, interconnected between them, is mutually influential, and each subsequent, higher level includes the previous levels, that is, it has a more powerful synergistic force.

The synergistic effect of socioeconomic exclusion can be clearly illustrated through the model of the planetary movement, namely the existence of the so-called "white" and "black" dwarfs [12]. "White" dwarfs by their very nature initiate the effect of enlargement, that is, they act as attractors, attracting other celestial bodies, absorb them, thereby increasing their size. The same phenomenon occurs with the social nature of society: the exclusion part attracts individual individuals or even social groups to one or another of them, which naturally becomes the basis for expanding socio-economic exclusion. That is, the transfer of the physical phenomenon of "white" synergetic to the tendencies of socio-economic life is taking place.

"Black" dwarfs, on the contrary, are compressed more and more, turning into a microscope, illustrating an example of "black" synergetic. This phenomenon reflects socio-economic engagement when excluded groups gradually dissolve in a larger socio-economic segment due to different social and economic incentives to attract them. In the economic-mathematical form, the phenomenon of "white" and "black" synergism of socioeconomic exclusion is represented by an expression (1).

Consequently, a positive socio-economic effect (avoiding socio-economic exclusion $\left(S_{\text {av.excl. }}\right)$ in the process of optimization planning the development of society should be maximized, and the negative socioeconomic effect (expansion of socio-economic exclusion $\left(S_{\text {epan.excl. }}\right)$ - minimize.

$$
\left\{\begin{array}{c}
S_{\text {av.excl. }}=\sum S_{\text {від }} \rightarrow \max , \\
S_{\text {epan.excl. }}=\sum S_{\text {від }} \rightarrow \min ,
\end{array}\right\}
$$


The synergistic effect of social and economic exclusion through a monetary expression can be defined as the difference between the magnitude of the synergistic effect at the macro level $\left(V \sum S_{\text {macr }_{t}}\right)$ taking into account the cost and effectiveness of applying the regulatory macroeconomic toolkit and the magnitude of the synergy effect at the micro level $\left(V \sum S_{\text {micr }_{t}}\right)$ in a certain period of time $(t)$ :

$$
\begin{gathered}
S_{t}=\left(V \sum S_{\text {macr }}\right)-\left(V \sum S_{\text {micr }}\right) \\
S_{t}=\left(B_{\text {macr }}-B_{\text {micr }}\right)+P+P_{t}
\end{gathered}
$$

where $B_{\text {macr }}$ - costs in the macro system, caused by the program of introducing proposals for socioeconomic involvement;

$B_{\text {micr }}-$ costs in the microsystem, as stipulated by the program of the introduction of the offer of socioeconomic attraction;

$P$ - net profit of the microsystem, arising from the elimination of socio-economic exclusion (the source of synergism), monetary units;

$P_{t}$ - net profit in microsystems that arises as a result of the elimination of socio-economic exclusion at a certain time at "intermediate" levels, monetary units.

Consequently, the synergetic effect of expanding socio-economic exclusion that occurs in society $S_{\alpha \beta}$-is the effect of the system $\alpha$ on the system $\beta$ :

$$
S_{\alpha \beta}=f\left(Z_{s}\right)
$$

where $Z_{s}$ - integrated, integral indicator, combining various variants of the synergetic effects of the socio-economic system.

The synergistic effect of "expansion" is the result of the impact of a particular retarded system on the environment, within which there is a disconnected system. The schematic representation of the synergistic effect of expanding socio-economic exclusion is presented in figure 2.

When considering it, it is necessary to consider that: $\alpha$ is a microsystem, $\beta$ is a macro system, while: $a \in \beta$, in the system $\beta$ includes $N$ levels: $\beta=\left\{N_{1}, N_{2}, N_{3}, \ldots, N\right\}$. At each $N$ level, there is a certain number of phases (q) of the retracting segment $\alpha$, that is, $N=\left\{q_{1}, q_{2}, q_{3}, \ldots, q\right\}$, which initiate the synergistic effect. For each $q$ object of the $\mathrm{N}$ level of the system $\beta$, there are different times to the onset of synergistic effect. Society (macro system $\beta$ ) has a permanent effect on the reversed microsystem $\alpha$, which in turn leads to the reciprocal effects of the phases of the rejected system $a$ on the macro system $\beta$. In other words, taking into account the synergistic effect of socio-economic exclusion is one of the parameters of a multi-level approach to the diagnosis of the welfare of the population at macro, meso- and micro levels. 

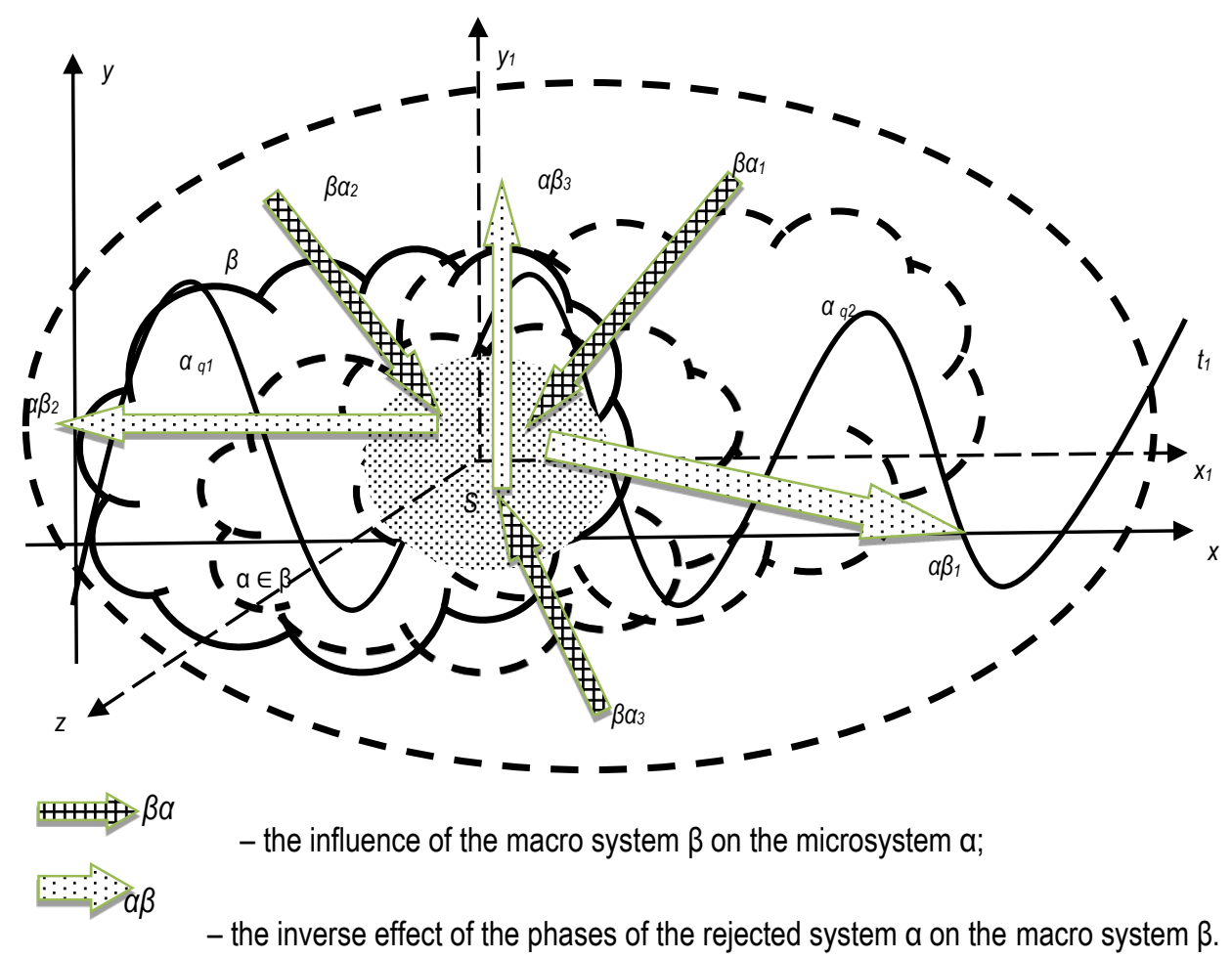

Figure 2-Scheme of the synergistic effect of the expansion of socio-economic exclusion

The results of the analysis of market sources of income, the artificial lowering of labour costs and the high share of social transfers of the population of Ukraine remain at the level of poverty according to European standards. The welfare of the Ukrainian population in 2014-2015 was influenced by the sufficient number of socio-economic indicators. Ukraine's GDP for the first quarter of 2015 in comparison with the first quarter of 2014 was $82.4 \%$, and compared with the 4th quarter of 2014 , taking into account the seasonal factor $-93.5 \%$. In January-April 2015 , the volume of industrial output decreased by $21.5 \%$, the consumer price index was $137.1 \%$, in annual terms, inflation exceeded $60 \%$. The unemployment rate of the population, determined by the ILO methodology, grew from $7.3 \%$ to $9.3 \%$ of the economically active population in the age group of 15-70 years. According to the estimates of the Ministry of Social Policy, the actual living wage for an able-bodied person in April 2015 was UAH 2317. The minimum wage (UAH 1218) was $44 \%$ of the actual living wage for able-bodied persons, taking into account compulsory payments (UAH 2783). UN experts ranked $75 \%$ of the Ukrainian population as poor. According to various experts, the gap in the incomes of the rich and poor population of Ukraine reaches 40 times, which poses a threat to the national security of the country and social stability. In our country, $1 \%$ of the population owns $70 \%$ of the country's wealth.

Table analysis results 2 indicate that disposable income per capita in 2015 compared to 2014 has significant disparities. The growth of this type of revenues in 2015 was in the Volyn, Kyiv, Kharkiv and Lviv regions on average by UAH 3,736, however, the significant decreasing in the Dnipropetrovsk, Donetsk, Luhansk and other Ukrainian regions. At the same time, a significant gap between the aggregate incomes of the population by regions is preserved. The difference between the maximum and the minimum 
V. Druzhynina, G. Likhonosova, G. Lutsenko. Assessment Welfare of the Population in the Synergetic System of Socio-Economic Exclusion

aggregate incomes of the population of regions for 2015 amounts to 121363 million UAH, for 2014 this difference is 119804 million UAH. In general, in the Ukraine, the level of income from 2014 to 2015 increased by 95987 million UAH [13].

Table 2 - Characteristics of the regions of Ukraine in accordance with the main economic indicators in 2014-2015 [13]

\begin{tabular}{|c|c|c|c|c|c|c|c|c|c|}
\hline \multirow{4}{*}{ 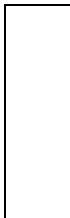 } & \multirow{4}{*}{ Countries } & \multicolumn{8}{|c|}{ Economic Indicators } \\
\hline & & \multirow{2}{*}{\multicolumn{2}{|c|}{$\begin{array}{l}\text { Welfare level of the } \\
\text { population }\end{array}$}} & \multicolumn{4}{|c|}{$\begin{array}{l}\text { Income as a characteristic of the standard of living } \\
\text { of the population }\end{array}$} & \multirow{2}{*}{\multicolumn{2}{|c|}{ GRP, $\%$}} \\
\hline & & & & \multicolumn{2}{|c|}{ Total million UAH } & \multicolumn{2}{|c|}{$\begin{array}{l}\text { Available income per } \\
\text { capita, UAH }\end{array}$} & & \\
\hline & & 2014 & 2015 & 2014 & 2015 & 2014 & 2015 & 2014 & 2015 \\
\hline \multicolumn{2}{|c|}{ Ukraine } & 3,3 & 3,6 & 1516768 & 1612755 & 26782,1 & 27712,3 & 106,0 & 110,2 \\
\hline 1 & Vinnitsa & 5,2 & 4,6 & 49418 & 53228 & 23421,7 & 23441,8 & 141,6 & 139,5 \\
\hline 2 & Volynregion & 4,3 & 4,3 & 27986 & 34123 & 20137,2 & 23117,5 & 120,1 & 121,4 \\
\hline 3 & Dnipropetrovsk & 1,9 & 1,8 & 136810 & 144345 & 32036,2 & 32015,2 & 98,2 & 97,3 \\
\hline 4 & Donetsk & 1,2 & 1,2 & 142745 & 140995 & 26234,4 & 26193,2 & 69,9 & 62,5 \\
\hline 5 & Zhytomyr & 4,8 & 4,7 & 36814 & 37824 & 22102,1 & 26115,9 & 126,6 & 121,5 \\
\hline 6 & Transcarpathian & 3,8 & 4,0 & 29988 & 24918 & 17358,1 & 16335,2 & 110,9 & 112,8 \\
\hline 7 & Zaporozhye & 1,7 & 1,5 & 68327 & 78333 & 30181,8 & 29115,4 & 97,1 & 96,4 \\
\hline 8 & Ivano-Frankivsk & 1,5 & 2,1 & 37848 & 40488 & 20356,7 & 24119,8 & 94,2 & 99,4 \\
\hline 9 & Kievskaya & 4,9 & 5,2 & 63342 & 67432 & 20356,7 & 24316,4 & 125,5 & 130,2 \\
\hline 10 & Kirovograd & 3,2 & 3,1 & 28901 & 26701 & 21954,1 & 22954,4 & 125,3 & 129,7 \\
\hline 11 & Lugansk & 1,3 & 1,1 & 56233 & 45253 & 19788,3 & 13988,8 & 47,7 & 43,3 \\
\hline 12 & Lviv & 3,6 & 4,1 & 79378 & 80338 & 23595,2 & 25596,1 & 110,4 & 115,2 \\
\hline 13 & Nikolaev & 2,1 & 2,1 & 36373 & 31333 & 23458,5 & 22468,2 & 104,9 & 107,1 \\
\hline 14 & Odessa & 4,1 & 4,3 & 80438 & 85238 & 24242,0 & 23255,2 & 115,5 & 117,8 \\
\hline 15 & Poltava & 1,4 & 1,6 & 49928 & 51298 & 26195,7 & 25169,1 & 88,3 & 93,5 \\
\hline 16 & Rivne & 3,7 & 3,8 & 33314 & 41318 & 21781,0 & 24788,9 & 110,6 & 111,2 \\
\hline 17 & Sumy & 3,1 & 3,4 & 35375 & 37315 & 23938,1 & 27939,2 & 108,4 & 105,2 \\
\hline 18 & Ternopil & 6,0 & 6,2 & 26892 & 22982 & 18400,5 & 21300,4 & 151,1 & 140,3 \\
\hline 19 & Kharkiv & 3,1 & 3,3 & 95897 & 99542 & 26274,0 & 32277,1 & 108,4 & 110,3 \\
\hline 20 & Kherson & 2,6 & 3,3 & 30077 & 41062 & 20727,9 & 32337,3 & 108,1 & 105,4 \\
\hline 21 & Khmelnitsky & 4,7 & 4,9 & 38853 & 36881 & 22686,1 & 21666,8 & 125,1 & 118,9 \\
\hline 22 & Cherkassy & 5,0 & 5,4 & 36694 & 47993 & 21760,5 & 25751,3 & 125,2 & 128,8 \\
\hline 23 & Chernivtsi & 4,2 & 4,1 & 22941 & 24791 & 18475,6 & 19376,8 & 117,5 & 120,4 \\
\hline 24 & Chernihiv & 2,0 & 2,2 & 31998 & 34998 & 23093,4 & 23591,2 & 104,6 & 103,5 \\
\hline
\end{tabular}

In the period 2014-2015, the best values of the welfare of the population are such areas as Zakarpattia, Kiev, Lviv, Odessa; remain on a par with Volyn, Donetsk, Mykolayiv and other regions in comparison with the previous year; The decline in the welfare of the population took place in Vinnitsa, Dnipropetrovsk, Kirovograd, Luhansk and Chernivtsi regions (Table 2). In 2014, the highest GRP per capita was produced in Vinnytsya (141.6\%), Zhytomyr (126.6\%), Ternopil (151.1\%) and Kyiv (125.5\%) oblasts. Among other regions characterized by high GRP per capita, this indicator decreased in 2015, compared with 2014 (Dnipropetrovsk - by $0.9 \%$, Zaporozhye - by $0.7 \%$, Sumy - by $3.2 \%$, Kherson - by $2.7 \%$, etc.). However, the growth of this indicator in 2015 was in Transcarpathian - by $1.9 \%$, Ivano-Frankivsk - by $5.2 \%$, 
Kirovograd region - by $4.4 \%$, Poltava region - by $5.2 \%$. The value of the GRP for Ukraine in general in 2015 compared with 2014 increased by $4.2 \%$. The high coefficients of the regional variation of the indicator also remained stable, varying from $28-33 \%$ during the study period. Taking into account the foregoing, the only possible way of constructing the forecast of regional human development is the study of the variation of indicators of the level and quality of life of the population of the regions by separate components and the integral indicator for the corresponding periods under study.

In determining the welfare of life at the sectoral level, it is necessary to take into account such indicators as specific wages, the degree of export orientation and import dependence of the industry, the degree of use of products in different industries, the level of alignment and progressiveness of research and development production and technological base, etc. The factors that affect these data include: provision of natural resources; opportunity and prospects of entrepreneurship development; technical, economic and organizational conditions for the creation, production and marketing of high quality products; presence of a group of highly competitive leading enterprises; sectoral infrastructure; a system of scientific, technical, production, logistical and commercial cooperation both within the industry and with others beyond its borders; an effective system of distribution of products, etc. [4, p. 10-15].

At the local level, the welfare of the population is estimated using indicators of local income and business activity and quality of working life; level of personnel qualification; the number of able-bodied people in the household and the level of qualification; pensions, assistance to the poor and the disabled, the level of social insurance, crime, etc. The factors influencing these indicators at the local level include housing infrastructure, various kinds of information, the system of local government, the quality of work of public safety bodies, the introduction of intellectual property in production, waste management, safety in the production of observance of constitutional human rights etc. For example, according to preliminary research, the city of Kremenchug of the Poltava region is the most successful and progressive city of the Poltava region [14; 15, p. 110-112]. The obtained welfare level $\left(\mathrm{W}_{\mathrm{lp} 0}\right)$ of the population of cities and districts of the Poltava region allows them to compare their characteristics and to choose the best and worst territories of the region (Figure 3). Kremenchug occupies leading positions in almost all spheres of activity and life support of the population. There is a tendency to increase volumes of realized industrial works and services and has a high level of integral indicator among regions and cities of the region.

This is because the city is a powerful industrial centre not only in the Poltava region but also in Ukraine as a whole. It concentrates a large number of the strategic companies and priority development areas that directly affect to the city's financial provision and the growth of the average wage, but due to the country's economic instability of our, the depreciation of the national currency and the high rate of inflation, real incomes of the population do not have rapid growth.

Regarding the employment of the population, Kremenchuk has a steady trend compared to other cities and regions, as the integral indicator of the number of employed in all spheres of economic activity is line $=1$. This happened because the decline in production of industrial products at the enterprises of the city led to an increase in the release of workers, but these issues are trying to solve through the opening of new jobs and temporary employment. 


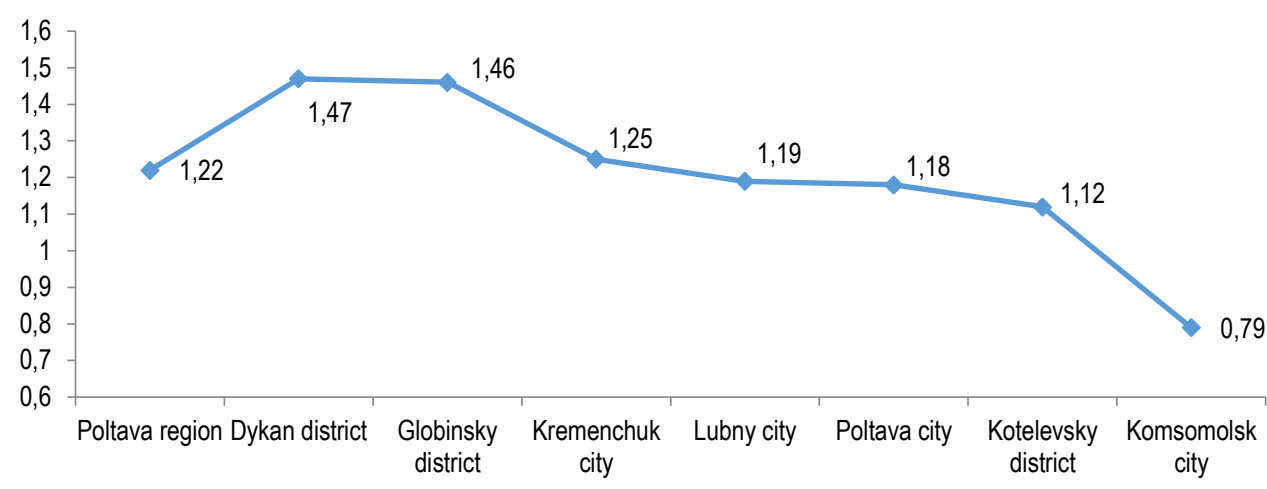

Figure 3 - The level of welfare of the population by regions and cities Poltava region

One of the areas in the system of state guarantees for the provision of job vacancies is paid public works, which are an effective tool for mitigating the situation on the labour market. In the reporting period, about 779 unemployed were sent to public works. However, unfortunately, the unemployment rate is increasing due to the difficult political and economic situation. As an additional tool for achieving wage consideration, it is recommended that the sub-minimum wage is set as a result of the formation of a twotiered minimum wage. Such a measure is possible for territories with a high level of economic development, such as Kremenchuk, and extends to borrowed extra budgetary sectors of the economy. The introduction of the sub-minimum will result in a reduction in unemployment among unskilled young people and people with disabilities, will provide an opportunity to obtain work experience, for which the employee will receive wages not lower than the level of labour productivity, and he will have incentives to upgrade to the needs of a particular enterprise [15, p. 110-112].

The fertility rates in Kremenchug are similar to those in the Poltava region in general but are slightly lower compared to other cities and districts. With regard to mortality, the indicator is higher than the average in the region and the life expectancy of the population is decreasing as in the country as a whole.

Describing the educational branch, one can say that the city of Kremenchug is one of the largest in the number of educational institutions of educational institutions and the number of students in these institutions. The city provides accessible and high-quality education in accordance with the modern requirements of society, the needs of the state, the region and the city. The integral value is $\mathrm{l}_{\mathrm{iv}}=1,02$ and has pronounced growth trends.

Worst of all the studied indicators is the introduction of real estate objects into operation, it is leso $=0,82$. Unfortunately, there is a clear decrease in this indicator, which negatively affects the overall level of welfare of the city.

The welfare of the population at the local level depends on the ability of the company to produce products more attractive to consumers regarding price and non-price characteristics; availability of an effective marketing strategy; level of management and qualification of the personnel; technological level of production; the tax environment in which the enterprise operates; availability of funding sources, etc. The quality of goods and services also affects the level of satisfaction of consumers' needs and is formed under the influence of technical and economic (quality, sales price and operating costs, production and sales costs, knowledge of products), commercial (market conditions, supply and demand, solvency, acuteness of competition, service, advertising, image), normative-legal factors. The list of all these factors is the basis of synergy, which there is either an exclusion or the involvement of a particular social segment in the identified society, which initiates the manifestation of these factors. 
Conclusions. Thus, it is necessary to note the following:

- firstly, a system of indicators for the assessment of the welfare of the population is generalized, taking into account its multilevel dimension. The complex of factors is determined, under the influence of which the level of welfare of the population changes;

- secondly, the multilevel measure of the welfare of the population should promote the receipt of the integral information on the state and problems of socio-economic development of the territories, the solution of which will ensure the improvement of the activities of state administration bodies at the state, regional and local levels, increase their role in addressing the issues of life support of the population of the territories;

Thirdly, the synergistic cycle of socio-economic exclusion, as an indicator for diagnosing the welfare of the population, takes place in a spiral. That is why, passing the same phases, this phenomenon never falls into the previous point, and every time it finds itself in a new state and manifests itself as a new dimension. If there is a synergistic effect of the "expansion" of the system of "white" synergetic, then the spiral of development will have a direction "to the mountain". If there is a synergistic effect of "black" synergetic, then the spiral of development has a direction of "decline";

Fourthly, in order to improve the well-being of the population at any level of the administrative-territorial division of the state, it is necessary to determine the growth vectors (stimulation of competitiveness, innovation processes and industries, the formation of a favourable climate for attracting investments, development of transport and road infrastructure, housing and communal reform improving the accessibility, quality and competitiveness of education by expanding the network of pre-school and general education taking into account the trends of the demographic situation and taking measures to abolish the queues for the placement of children in pre-school institutions, raising the level of coverage of children with complete general secondary, preschool and out-of-school education, capital repairs of educational infrastructure, reforming the health care system, improving quality and availability of medical services, modernization of primary medical care, strengthening of the material and technical base (equipment / reequipment) consulting and diagnostic Entry; raising the level of social security of the inhabitants, etc.), which should be aimed at mobilizing and concentrating all possible resources for the implementation of tasks related to the reform of the economy, the development of economic potential and the achievement of European standards of living.

The task of society is to level the negative consequences of the reverse ties of the exclusion of the social segment of the general direction of the functioning of the socio-economic system. The spread of socio-economic exclusion and its phases in combination with synergistic factors can lead to unpredictable devastating effects, so this phenomenon requires further detailed study and interpretation of its manifestations at local, national and world levels. The proposed vectors will provide an opportunity to formulate a strategy for the development of territories. This issue will be devoted to the following research.

1. Bywalec, C. (1991). Rozwój gospodarczy a poziom życia ludności. Społeczne aspekty gospodarowani [Economic development and the standard of living of the population. Social aspects of management]. Ruch Prawniczy, Ekonomiczny Socjologiczny, 4, $191-202$.

2. Libanova, E.M. (2007). Lyudskyy rozvytok rehioniv Ukrayiny: analiz ta prohnoz (kolektyvna monohrafiya) [Human Development of the Regions of Ukraine: Analysis and Forecast (Collective, Monograph)]. Kyiv: Institute of Demography and Social Studies of the National Academy of Sciences of Ukraine, 367.

3. Priyamak, V.I. (2001). Nechitke otsinyuvannya rivnya ekonomichnoho dobrobutu domohospodarstv [Fuzzy assessment of the level of economic welfare of households]. Economy: Realities of Time, 1(1), 149-158.

4. Makarova, O. V. \&Gladun, O. M. (2012). Rehionalnyy indeks lyudskoho rozvytku: prychyny ta napryamy vdoskonalennya metodyky rozrakhunku [Regional index of human development: causes and directions of the perfection of the calculation method] Statistics of Ukraine, 1, 10-15.

5. Levchenko, A.V. (2014). Zakonydialektyky v konteksti synerhetychnoyi paradyhmy rozvytku [Laws of dialectics in the context of a synergetic paradigm of development]. Philosophy and political science in the context of modern culture, 7, 101-106. 
6. Likhonosova, G. (2016). Synerhetychnyy efekt poshyrennya sotsialno-ekonomichnoho vidtorhnennya [The synergistic effect of the spread of socio-economic exclusion]. Scientific Journal "Smart Yaung", 3, 2, 22-28.

7. Guz, M.M. (2012). Analiz pokaznykiv ekonomichnoho ta suspilnoho dobrobutu naselennya [Analysis of indicators of the economic and social welfare of the population]. Problems and prospects of development of the banking system of Ukraine, 36, 6674.

8. Official site of the United Nations Department of Statistics. Retrieved from http://unstats.un.org/unsd/publication/SeriesF/SeriesF_22E.pdf.

9. Ignatyuk, A.O. (2010). Metodychni pidkhody do vymiryuvannya rozvytku suspilnoho dobrobutu [Methodical approaches to the measurement of the development of public welfare]. Economic Space, 34, 53-65.

10. Melnichenko, O. A. (2007). Sotsialni indykatory rivnya ta yakosti zhyttya naselennya yak rezultat rehulyatornoho vplyvu derzhavy [Social indicators of the level and quality of life of the population as a result of the regulatory influence of the state]. Actual problems of public administration, 2(32), 218-226.

11. Schumpeter, J. (1982). Teoriya ekonomicheskogo razvitiya: issledovaniye predprinimatel'skoy pribyli, kapitala, kredita, protsenta i tsikla konyunktury [Theory of economic development: the study of entrepreneurial profit, capital, credit, interest and the cycle of the conjuncture], Moscow, 200.

12. Shapiro, S. L. \& Tukolski, S. A., \& Smorodinsky, J. A. (1985). Chernyye dyry belyye karliki I neytronnyye zvezdy [Black holes, white dwarfs and neutron stars]. Moscow: Mir, 1-2, 656.

13. Ofitsiynyy sayt Derzhavnoyi sluzhby statystyky Ukrayiny [Official site of the State Statistics Service of Ukraine]. Retrieved from: http://www.ukrstat.gov.ua.

14. Druzhynina, V.V. (2014). Mistsevyy rynok pratsi: umovy funktsionuvannya, metody ta sposoby zabezpechennya zbalansovanosti [Local labor market: conditions of functioning, methods and methods of balancing]. Donetsk: South-East, 365 .

15. Druzhynina, V.V. \& Alekseeva, N.F. \& Zalunina, O. M. (2017). Formuvannya bahatorivnevoyi systemy pokaznykiv vymiru dobrobutu naselennya [Formation of a multi-level system of indices of welfare measurement]. Actual problems of the economy, $4(190), 100-112$.

В.В.Дружиніна, д.е.н., професор, Кременчуцький національний університет імені Михайла Остроградського (Кременчук, Україна);

Г. С. Ліхоносова, к.е.н, доцент, Національний аерокосмічний університет імені М. Є. Жуковського «Харківський авіаційний інститут» (Харків, Україна);

Г. П. Луценко, викладач-методист вищої категорії, Кременчуцький льотний коледж Національного аерокосмічного університету імені М. Є. Жуковського «Харківський авіаційний інститут» (Кременчук, Україна).

Оцінювання добробуту населення в синергетичній системі соціально-економічного відторгнення

Дослідження присвячено систематизації найважливіших соціальних, економічних та інші видів детермінант, врахування яких дозволить здійснити комплексну багаторівневу діагностику добробуту населення країни Багаторівневість запропонованого підходу до діагностики добробуту населення проявляється у тому, що ї запропоновано здійснювати на міжнародному, національному, регіональному, місцевому та локальному рівнях. В статті доведено, що так зване "соціально-економічне відторгнення» є результатом закону синергетичного розвитку системи, тобто закону, який виражає внутрішньо необхідні, стійкі зв'язки між елементами системи. Результатом дослідження стала також узагальнена система показників оцінки добробуту населення з урахуванням його багаторівневого вимірювання. Виділено комплекс чинників, під впливом яких змінюється рівень добробуту населення. Практичне значення одержаних результатів полягає в тому, що розроблені методологічні основи та прикладний інструментарій багаторівневої діагностики добробуту населення дозволить нейтралізувати негативні наслідки відторгнення сприятиме зростанню якості благоустрою населення в різних регіонах. Стаття містить також і результати проведених авторами досліджень щодо оптимального вибору інструментів для подолання існуючих проблем диспропориій в суспільстві. Застосування багаторівневого підходу до діагностики добробуту населення безпосередньо вплине на забезпечення якості життя населення і досягнення прогресу у соціально-економічному розвитку. Уникнути регіональних диспропориій розвитку та процесів відторгнення, що відбуваються в державі, можливо через диференціацію інструментарію оцінювання соціально-економічного розвитку регіонів з урахуванням специфіки кожного з них. Моніторинг узгодженості дій громад, урядових організацій забезпечить досягнення високого рівня якості життя населення, що дозволить кожному окремому члену суспільства реалізовувати власні раціонально-егоїстичні цілі розвитку, запустить ланцюг зворотного зв'язку з отриманням мультиплікативного позитивного ефектту.

Ключові слова: добробут, багаторівневий підхід, оцінювання, соціально-економічна ізоляція, синергія. 